\title{
Thrombin-induced Exposure and Prostacyclin Inhibition of the Receptor for Factor VIII/von Willebrand Factor on
}

\section{Human Platelets}

\author{
Takayoshi Fujimoto, Shigekazu Ohara, and Jack Hawiger, Departments of \\ Pathology and Medicine, Vanderbilt University School of Medicine, \\ Nashville, Tennessee 37232
}

\begin{abstract}
A B S T R A C T The receptor for Factor VIII/von Willebrand factor (F. VIII $\mathrm{VWF}_{\mathrm{VF}}$ ) is not readily available on circulating platelets. We have found that the stimulation of platelets with traces of thrombin at concentrations that are generated physiologically $(0.008 \mathrm{U}-$ $0.05 \mathrm{U} / \mathrm{ml}$ ) induced concentration-dependent binding of ${ }^{125} \mathrm{I}$-labeled F. VIII $\mathrm{VWF}_{\mathrm{VWF}}$ in a steady-state system. The binding induced by thrombin was specific because it was inhibited by a 100-fold molar excess of unlabeled

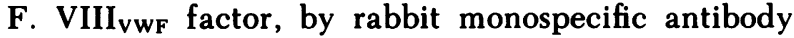
against Factor VIII, and was not inhibited by an excess of fibrinogen or fibronectin. Binding induced by thrombin required metabolically active platelets, in contrast to a system with ristocetin that also prompted binding to glutaraldehyde-treated platelets. The thrombin effects on binding of ${ }^{125} \mathrm{I}-\mathrm{F}$. VIII $\mathrm{VWF}_{\mathrm{VWF}}$ was not observed when platelets were washed with EDTA-containing buffers; EDTA and EGTA both inhibited thrombin-induced binding. Platelet membrane glycoproteins were required because enzymatic stripping of them from the platelet surface with chymotrypsin reduced binding 2.5-5.0-fold. Prostacyclin, in the concentration range of 1 to $50 \mathrm{nM}$, had two distinct effects on the receptor for $\mathrm{F}$. VIII $\mathrm{VWF}_{\mathrm{VF}}(a)$ it prevented exposure of this receptor when added $10 \mathrm{~min}$ before thrombin, and $(b)$ it reversed the binding of ${ }^{125} \mathrm{I}-\mathrm{F}$. VIII $_{V W F}$ to the platelet receptor when added $30 \mathrm{~min}$ after thrombin and the ligand, i.e., when binding was at equilibrium. The dual effect of prostacyclin on the receptor for $\mathrm{F}$. VIII $\mathrm{VWF}_{\mathrm{F}}$ was reproduced by dibutyryl cyclic AMP.
\end{abstract}

This work was presented in part at the meetings of the American Society of Hematology, Phoenix, AZ. 1979. Blood. 54: 294, and of the American Association of Physicians, San Francisco, CA. 1981. Clin. Res. 29: 571A.

Address reprint requests to Dr. Hawiger.

Received for publication 24 August 1981 and in revised form 5 February 1982.

\section{INTRODUCTION}

Formation of a platelet plug at the site of vascular injury is of fundamental importance in normal hemostasis. Plasma Factor VIII/von Willebrand factor $\left(\mathrm{F} \text {. VIII } \mathrm{VWF}_{\mathrm{VWF}}\right)^{1}$ is required for the interaction of platelets with an injured vessel wall (1). Individuals lacking this glycoprotein demonstrate a bleeding tendency, owing to their inability to form a functionally competent hemostatic plug (2). However, the exact in vivo mechanism(s) of the interaction between platelets and $F$. VIII $_{\mathrm{VWF}}$ is not known.

Under normal physiologic conditions, plasma $\mathrm{F}$. VIII $_{\mathrm{VWF}}$ is loosely associated with platelets. After their removal from the plasma atmosphere, such platelets do not adhere to the subendothelial space in a rabbit aorta, and they do not aggregate in the presence of the antibiotic ristocetin $(3,4)$. Aggregation or agglutination of platelets in the presence of ristocetin requires $\mathrm{F}$. VIII $\mathrm{VWF}_{\mathrm{VF}}$, and this factor becomes tightly "associated" with human platelets (5-8). It has been recently reported that ristocetin induces binding of 31,000 molecules of $\mathrm{F}$. VIII $\mathrm{VWF}_{\mathrm{VW}}\left(M_{r} 1.1 \times 10^{6}\right)$ per one platelet (9). This ristocetin-induced binding of $F$. VIII $_{V W F}$ is of relatively high affinity and demonstrates a functional correlation with platelet aggregation (10). Whereas ristocetin is a useful laboratory tool to study and diagnose abnormalities in the interaction of von Willebrand factor with human platelets (4), we undertook a search for a physiologic mechanism(s) that can be operative in vivo to induce and regulate the interaction of $F$. VIII ${ }_{V W F}$ with human platelets.

Our results indicate that thrombin at concentrations that are generated physiologically (11) allows F.

\footnotetext{
${ }^{1}$ Abbreviations used in this paper: AGFP, albumin gra-

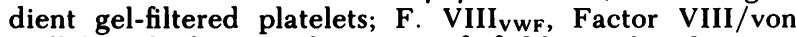
Willebrand factor; dcAMP, $\mathrm{N}^{6} \mathrm{O}^{2}$-dibutyryl adenosine 3',5'monophosphate cyclic AMP; $\mathrm{PGI}_{2}$, prostacyclin; 6-keto $\mathrm{PGF}_{1 \alpha}, 6$-keto-prostaglandin $\mathrm{F}_{1 \alpha}$.
} 
VIII $_{\mathrm{VWF}}$ to bind to platelets. Because there is evidence for thrombin activity and for formation of fibrin appearing very promptly at the site of a vascular wound $(1,11,12)$, the ability of thrombin to induce binding of F. VIII ${ }_{\mathrm{VWF}}$ can represent one of the important mechanisms governing formation and/or growth of a hemostatic plug. On the other hand, prostacyclin $\left(\mathrm{PGI}_{2}\right)$, a known inhibitor of platelet aggregation produced by endothelial cells $(13,14)$ lining the vessel in the vicinity of a vascular injury, is a likely agent to be involved in prevention of $\mathrm{F}$. VIII $\mathrm{VWF}_{\mathrm{VW}}$-mediated interaction of platelets with the vessel wall. Indeed, prostacyclin has proven to be not only inhibitory toward exposure of the receptor for $F$. VIII $\mathrm{VWF}_{\mathrm{WF}}$ by thrombin, but even more striking, it was also able to reverse the binding of already attached F. VIII ${ }_{\mathrm{VwF}}$.

\section{METHODS}

Materials. Human F. VIII concentrate was obtained from American National Red Cross. Ristocetin, human thrombin ( $>90 \%$ homogeneity, 3,000 National Institutes of Health [(NIH) Units/mg], EDTA, EGTA, polyethelyne glycol (mol wt 4,000), and diisopropylfluorophosphate were purchased from Sigma Chemical Co., St. Louis, MO. Bovine thrombin was purchased from Parke, Davis \& Co., Detroit, MI. Purified human $\alpha$-thrombin (sp act $2,730 \mathrm{U} / \mathrm{mg}$ ) was obtained through the courtesy of Dr. John Fenton III (New York Department of Public Health, Albany, NY) and Dr. Leon Cunningham (Vanderbilt University, Nashville, TN). Human fibrinogen was purchased from Kabi, Stockholm, Sweden. Rabbit antihuman fibrinogen immunoglobulin G (IgG) was purchased from N. L. Cappel Laboratories, Inc., Cochranville, $\mathrm{PA}$, rabbit antihuman $\mathrm{F}$. VIII and dibutyryl cyclic AMP (dcAMP) from Calbiochem-Behring Corp., American Hoechst Corp., San Diego, CA. Bio-Gel A 15m was purchased from Bio-Rad Laboratories, Richmond, CA. Sepharose 4B and $2 B$ were purchased from Pharmacia Fine Chemicals, Piscataway, NJ. Both ${ }^{125} \mathrm{I}$ - and $\left[{ }^{3} \mathrm{H}\right]$ serotonin were purchased from Amersham Corp., Arlington Hts., IL. Imipramine was obtained from Ciba-Geigy Corp., Summit, NJ. Alpha chymotrypsin $(49.2 \mathrm{U} / \mathrm{mg})$ was purchased from Worthington Biochemical Corp., Freehold, $\mathrm{NJ} \mathrm{PGI}_{2}$ and 6-keto prostaglandin $F_{1 \alpha}\left(6\right.$ keto $\left.\mathrm{PGF}_{1 \alpha}\right)$ were obtained through the courtesy of Dr. John Pike, Upjohn Co., Kalamazoo, MI.

Preparation of albumin gradient gel-filtered platelets (AGFP). Blood was drawn from normal healthy donors, who had not taken any medication in the previous $2 \mathrm{wk}$, into

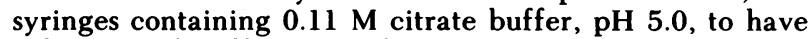
a final blood buffer ratio of 9:1. It was centrifuged at 160 $g$ for $15 \mathrm{~min}$. The platelet-rich plasma was collected, layered on the top of a stepwise albumin gradient, and after centrifugation, the layer of platelets was filtered through a Sepharose 2B column equilibrated with Hepes buffer, pH 7.35, containing $0.1 \%$ dextrose and $0.35 \%$ albumin (15). Fractions from the first peak were collected, and platelets were counted in a Coulter model ZBI particle counter (Coulter Electronics Inc., Hialeah, FL). AGFP were used in experiments unless otherwise stated.

Preparation of glutaraldehyde-fixed platelets. Platelets obtained by the stepwise albumin gradient-gel filtration method were fixed with an equal volume of $0.1 \%$ glutaraldehyde containing $0.14 \mathrm{M} \mathrm{NaCl}, 5 \mathrm{mM}$ EDTA, $5.5 \mathrm{mM}$ glu-

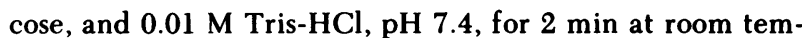
perature (16). Fixed platelets were centrifuged, washed three times in the above buffer from which glucose was omitted, and used for the experiment the next day.

Preparation of washed platelets. The procedure of Kao et al. (9) was followed. Briefly, platelet-rich plasma was obtained as above and centrifuged at $6,000 \mathrm{~g}$ for $10 \mathrm{~min}$ at room temperature. The platelet pellet was washed five times by resuspending it in $16 \mathrm{ml}$ of $0.025 \mathrm{M}$ Tris- $\mathrm{HCl}, 0.15 \mathrm{M}$ $\mathrm{NaCl}, 0.01 \mathrm{M}$ EDTA, pH 7.4, and centrifuging at $6,000 \mathrm{~g}$ for $10 \mathrm{~min}$ at room temperature. After the last wash, the platelets were resuspended in $0.025 \mathrm{M}$ Tris- $\mathrm{HCl}, 0.15 \mathrm{M}$ $\mathrm{NaCl}, 0.1 \%$ bovine serum albumin, pH 7.4.

Chymotrypsin treatment of platelets. Albumin gradient gel-filtered platelets were treated with chymotrypsin (300 $\mu \mathrm{g} / \mathrm{ml}$ ) for $30 \mathrm{~min}$ and then the reaction was stopped with $0.5 \mathrm{mM}$ toluenesulfonyl fluoride. Untreated platelets were processed in a similar way but without addition of chymotrypsin.

Preparation of $\left[{ }^{3} \mathrm{H}\right]$ serotonin-labeled platelets (AGFP) was done as described (17). The final count of platelets was adjusted to $1.0 \times 10^{8}$ platelets in each sample, and the release reaction was performed at room temperature without stirring. Samples were taken for total radioactivity counts, the incubation mixture centrifuged at $8,000 \mathrm{~g}$ for $2 \mathrm{~min}$, and the supernatant assayed for released radioactivity. Imipramine, at a concentration of $0.15 \mu \mathrm{g} / \mathrm{ml}$, was used in all release experiments.

Purification of F. VIII $I_{V W F}$. The general procedure of Sodetz et al. (18) was followed with two added modifications. Briefly, human F. VIII concentrate (807-915 NIH units) was precipitated with polyethylene glycol. The precipitate was washed and dissolved in $0.05 \mathrm{M}$ Tris- $\mathrm{HCl}, 0.15 \mathrm{M} \mathrm{NaCl}, 1$

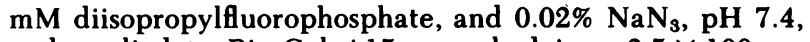
and applied to Bio-Gel A15 m packed in a $2.5 \times 100-\mathrm{cm}$ siliconized glass column. The column was eluted with a solution of $0.05 \mathrm{M}$ Tris- $\mathrm{HCl}, 0.15 \mathrm{M} \mathrm{NaCl}$, and $0.02 \% \mathrm{NaN}_{3}$, pH 7.4. The void volume fractions containing $F$. VIII procoagulant activity were pooled and precipitated at $4^{\circ} \mathrm{C}$ by the addition of solid ammonium sulfate until $35 \%$ saturation was attained. The precipitate was dissolved in $0.05 \mathrm{M}$ phosphate, $0.15 \mathrm{M} \mathrm{NaCl}, \mathrm{pH} 8.0$, and dialyzed at $4^{\circ} \mathrm{C}$ against the same buffer. To remove traces of fibrinogen, dialyzed, purified material was applied to an antihuman fibrinogen IgGSepharose 4B affinity column prepared as described below. The column was eluted at room temperature with $0.05 \mathrm{M}$ phosphate, $0.15 \mathrm{M} \mathrm{NaCl}$, (pH 8.0), $0.01 \mathrm{M}$ glycine-HCl (pH 2.2), and $6 \mathrm{M}$ urea, $0.05 \mathrm{M}$ phosphate, (pH 6.0). Fractions eluted with $0.05 \mathrm{M}$ phosphate, $0.15 \mathrm{M} \mathrm{NaCl}, \mathrm{pH} \mathrm{8.0,} \mathrm{were}$ combined and precipitated by the addition of solid ammonium sulfate until $35 \%$ saturation was attained. The precipitate was collected by centrifugation at $12,000 \mathrm{~g}$ for $10 \mathrm{~min}$, dissolved in the same buffer, and dialyzed. In some experiments, this material was subjected to an additional step of purification to remove fibronectin, using gelatin-Sepharose 4B affinity chromatography as described below (19).

Labeling of F. VIII $I_{V W F}$. Purified F. VIII ${ }_{\mathrm{VWF}}$ was labeled with ${ }^{125} \mathrm{I}$, using the iodine monochloride technique of McFarlane (20). The specific radioactivity of ${ }^{125} \mathrm{I}-\mathrm{F}$. VIII $\mathrm{VWF}_{\mathrm{VWF}}$ was on average $5.4 \times 10^{8} \mathrm{cpm} / \mathrm{mg}$, and $95 \%$ radioactivity was precipitated with $10 \%$ TCA. The activity of F. VIII VwF $_{\text {F }}$ was assayed for the ristocetin-cofactor activity before and after radioiodination using platelets separated by a stepwise albumin gradient-gel filtration method. In a twofold dilution method, both iodinated F. VIII $\mathrm{VwF}_{\mathrm{W}}$ and unlabeled protein after affinity chromatography with antifibrinogen IgG had 74 units of ristocetin cofactor activity per milligram 
protein. Before affinity chromatography, the ristocetin-cofactor activity was, on the average, $56 \mathrm{U} / \mathrm{mg}$ protein.

Binding of ${ }^{125} I-F$. VIII $I_{V W F}$ to platelets. All binding assays were performed in $0.5 \mathrm{ml}$ reaction mixture containing from $5 \times 10^{7}$ to $1 \times 10^{8}$ platelets. Platelets were preincubated with thrombin or ristocetin for 3 to $5 \mathrm{~min}$, and then ${ }^{125} \mathrm{I}-\mathrm{F}$. VIII $\mathrm{VWF}_{\mathrm{WF}}$ was added to each sample. When thrombin was used, hirudin in concentration of $0.2 \mathrm{U}$ was added for $2 \mathrm{~min}$ to neutralize unbound thrombin. The sample was incubated at room temperature in polypropylene tubes $(12 \times 75 \mathrm{~mm})$ for an additional $50 \mathrm{~min}$ without agitation. After incubation, the mixture was applied to the top of a 9:1 ( $\mathrm{vol} / \mathrm{vol})$ mixture of dibutylphthalate and Apiezon oil C (James G. Biddle Co., Plymouth Meeting, PA), and the platelets were separated from unbound ${ }^{125} \mathrm{I}-\mathrm{F}$. VIII $\mathrm{VWF}_{\mathrm{VWF}}$ by centrifugation for about $2 \mathrm{~min}$ at $8,000 \mathrm{~g}$ using a microfuge $(21)$. The supernatant was sampled for free radioactivity, and bound radioactivity was measured in the platelet pellet cut off together with the tip of the tube after rapid freezing of its contents in a mixture of dry ice and acetone. Their radioactivities were determined in a Searle Gamma Counter (Searle Radiographics Inc., Des Plaines, IL). Specific binding was determined by subtracting from the observed amount of bound ${ }^{125} \mathrm{I}-\mathrm{F}$. VIII $_{\mathrm{VWF}}$ that amount which bound in a duplicate incubation mixture containing 100 -fold $\mathrm{M}$ excess of unlabeled $\mathrm{F}$. VIII $\mathrm{VWF}_{\mathrm{vw}}$. The amount of ${ }^{125} \mathrm{I}-\mathrm{F}$. VIII $\mathrm{VWF}_{\mathrm{VF}}$ bound in the presence of an excess of unlabeled ligand ranged from 10 to $22 \%$ of the observed ${ }^{125} \mathrm{I}-\mathrm{F}$. VIII $\mathrm{VWF}_{\mathrm{VWF}}$ bound to platelets stimulated with thrombin. The amount of ${ }^{125} \mathrm{I}-\mathrm{F}$. VIII $\mathrm{VWF}_{\mathrm{VW}}$ associated with unstimulated control platelets was very similar in the absence and presence of an excess of unlabeled F. VIII ${ }_{\mathrm{VWF}}$.

Preparation of fibrinogen-Sepharose $4 B$ column. Human fibrinogen was dissolved in distilled water to a final concentration of $0.3 \%$ and then dialyzed against $0.15 \mathrm{M} \mathrm{NaCl}$. A saturated solution of ammonium sulfate was added to the solution with stirring to give $16 \%$ saturation. The fibrin-like material was collected on a glass rod, redissolved in $0.15 \mathrm{M}$ $\mathrm{NaCl}$, and then precipitated once more by the addition of ammonium sulfate until $16 \%$ saturation was attained (22). The final product of fibrinogen was coupled to Sepharose 4B (23).

Preparation of monospecific antihuman fibrinogen IgGSepharose $4 B$ column. Rabbit antihuman fibrinogen IgG was dissolved in $0.015 \mathrm{M}$ Tris- $\mathrm{HCl}, 0.14 \mathrm{M} \mathrm{NaCl}, \mathrm{pH} \mathrm{7.5 \text {, }}$ and then dialyzed against the same buffer. After dialysis, the solution was applied to a fibrinogen-Sepharose 4B affinity column and eluted in sequence with $0.15 \mathrm{M}$ Tris- $\mathrm{HCl}$, $0.14 \mathrm{M} \mathrm{NaCl}, \mathrm{pH} 7.5 ; 0.1 \mathrm{M}$ carbonate, $\mathrm{pH} 9.7 ; 1 \mathrm{M} \mathrm{NaCl}$, $0.015 \mathrm{M}$ Tris- $\mathrm{HCl}, \mathrm{pH} 7.5 ; 0.1 \mathrm{M}$ glycine- $\mathrm{HCl}, \mathrm{pH} 2.2$; and $4 \mathrm{M}$ urea, $0.05 \mathrm{M}$ phosphate, pH 6.0 (23). The eluates with $0.1 \mathrm{M}$ glycine- $\mathrm{HCl}, \mathrm{pH} 2.2$; and with $4 \mathrm{M}$ urea, $0.05 \mathrm{M}$ phosphate, pH 6.0, were collected and concentrated, respectively. After checking the purity and specificity of antihuman fibrinogen IgG, the material was coupled to Sepharose 4B (23)

Preparation of fibronectin. Gelatin-Sepharose 4B was used to isolate fibronectin and to separate fibronectin from purified F. VIII $\mathrm{VwF}$. The sample was applied to gelatin-Sepharose $4 \mathrm{~B}$ with $0.05 \mathrm{M}$ phosphate, $0.15 \mathrm{M} \mathrm{NaCl}, \mathrm{pH} \mathrm{7.2,}$ and fibronectin was eluted with $8 \mathrm{M}$ urea, $0.05 \mathrm{M}$ Tris- $\mathrm{HCl}$, pH 7.5 (19).

Sodium dodecyl sulfate polyacrylamide gel electrophoresis (SDS-PAGE). Electrophoresis was performed according to the procedure of Weber and Osborn (24). Samples were reduced in the presence of $1 \%$ dithiothreitol at $37^{\circ} \mathrm{C}$ for $30 \mathrm{~min}$. The percentages of acrylamide used for electrophoresis were either 5 or $7.5 \%$.

Other assays. Protein concentrations in the samples were measured by the method of Lowry (25). Fibrinogen content of purified F. VIII $\mathrm{VWF}_{\mathrm{WF}}$ was checked with the staphylococcal clumping test which can detect $0.5 \mu \mathrm{g}$ fibrinogen $/ \mathrm{ml}(26)$ and by radioimmunoassay detecting at least $10 \mathrm{ng}$ of fibrinogen per milliliter. Immunodiffusion reactions were performed by the double diffusion method of Ouchterlony (27) using the diffusion plates prepared with $1.2 \%$ agar in veronal buffer, $\mathrm{pH} 8.5, I=0.5$.

\section{RESULTS}

We have used purified ${ }^{125} \mathrm{I}-\mathrm{F}$. VIII $\mathrm{VWF}_{\mathrm{VWF}}$ for quantitative binding studies. F. VIII $\mathrm{VWF}_{\mathrm{VF}}$ isolated from human Factor VIII concentrate by a standard procedure (18), was purified further by affinity chromatography to assure removal of fibrinogen and fibronectin, which contaminate Factor VIII preparations (28). Such purified F. VIII $_{V W F}$ gave a single band on SDS-PAGE under reducing conditions. Electrophoresis of iodinated F. VIII $_{\text {VWF }}$ produced a single peak of radioactivity that was parallel with the protein band (Fig. 1, top panel). Whereas fibrinogen was present in concentrations of $22 \mu \mathrm{g} / 1 \mathrm{mg}$ of preparations of $\mathrm{F}$. VIII $\mathrm{VWF}_{\mathrm{F}}$ before immunoaffinity chromatography, it was not detected thereafter using immunodiffusion or the staphylococcal clumping test with a limit of detectability $0.5 \mu \mathrm{g}$

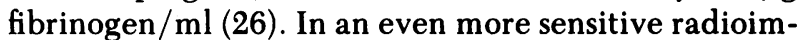
munoassay procedure, the fibrinogen content was $<60$ $\mathrm{ng} / 1 \mathrm{mg}$ of F. VIII $\mathrm{VWF}$, i.e., $<0.00006 \%$ of F. VIII $\mathrm{VWF}$ weight.

Human platelets used in these experiments were essentially free of plasma $\mathrm{F}$. VIII $\mathrm{VWF}_{\mathrm{VWF}}$, as judged by a complete lack of responsiveness to ristocetin. They were also separated from plasma fibrinogen, as verified by the lack of a response to ADP and by the absence of detectable plasma fibrinogen in the supernatant of sedimented platelets, using the staphylococcal clumping test. These platelets maintained their reactivity to thrombin in terms of aggregation and release of $\left[{ }^{3} \mathrm{H}\right]$ serotonin for at least $120 \mathrm{~min}$ after separation.

Binding of F. VIII $I_{V W}$ to human platelets. Binding of ${ }^{125} \mathrm{I}-\mathrm{F}$. VIII $\mathrm{VWF}_{\mathrm{VW}}$ was observed when platelets were treated with thrombin in a concentration of $0.05 \mathrm{U} /$ $\mathrm{ml}$. At this concentration, the equilibrium of binding occurred within $30 \mathrm{~min}$ (Fig. 2). Because we were testing lower thrombin concentrations as well, 60-min incubations were usually performed. In subsequent experiments, different concentrations of thrombin, ranging from $0.001 \mathrm{U} / \mathrm{ml}$ to $1 \mathrm{U} / \mathrm{ml}$, were tested. The extent of ${ }^{125} \mathrm{I}-\mathrm{F}$. VIII $\mathrm{VWF}_{\mathrm{VW}}$ binding was proportional to the thrombin concentration added to the platelets before ${ }^{125} \mathrm{I}-\mathrm{F}$. VIII $\mathrm{VWF}_{\mathrm{VW}}$ (Fig. 3). Binding of F. VIII $\mathrm{VWF}$ to platelets was significantly induced with as little throm- 

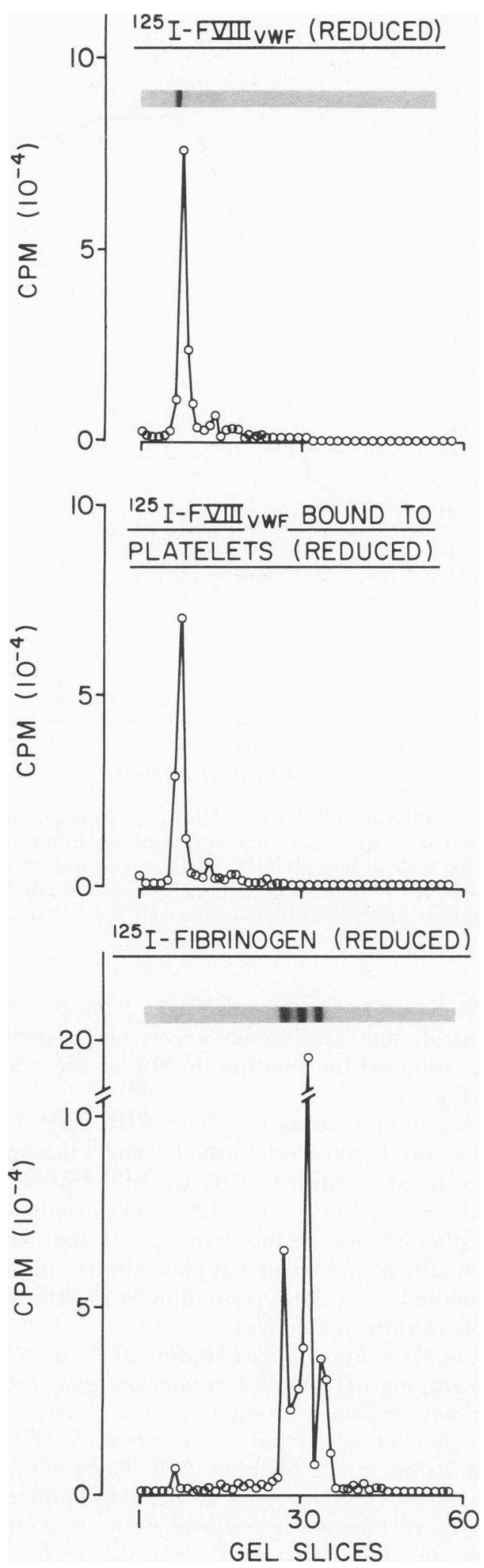

bin as $0.008 \mathrm{U} / \mathrm{ml}$, reaching a maximum at thrombin concentrations of $0.01 \mathrm{U} / \mathrm{ml}-0.05 \mathrm{U} / \mathrm{ml}$. Above this range, thrombin caused some decrease in binding of ${ }^{125} \mathrm{I}-\mathrm{F}$. VIII $\mathrm{VWW}_{\mathrm{WF}}$. Therefore, in most experiments presented below, we used thrombin at a concentration of $0.05 \mathrm{U} / \mathrm{ml}$. Bovine thrombin and two different human $\alpha$-thrombin preparations (one purified and provided by Dr. John Fenton III) produced a similar effect when tested with the same platelet preparation in terms of binding results.

Thrombin was required for its action on platelets and not on ${ }^{125} \mathrm{I}-\mathrm{F}$. VIII $\mathrm{VWF}_{\mathrm{VWF}}$, because preincubation of ${ }^{125} \mathrm{I}-\mathrm{F}$. VIII $_{\mathrm{VWF}}$ with thrombin, followed by inactivation of free thrombin with hirudin, did not result in increased binding of ${ }^{125} \mathrm{I}-\mathrm{F}$. VIII $\mathrm{VWF}_{\mathrm{VWF}}$ to untreated platelets. Furthermore, ${ }^{125} \mathrm{I}-\mathrm{F}$. VIII $\mathrm{VWWF}_{\mathrm{VWF}}$ bound to platelets was analyzed in SDS-PAGE under reducing conditions. The radiolabeled protein pattern remained the same as ${ }^{125} \mathrm{I}-\mathrm{F}$. VIII $_{\mathrm{VWF}}$ analyzed before binding to platelets (Fig. 1, middle panel). The platelet-associated ${ }^{125}$ I pattern did not exhibit radioactivity associated with ${ }^{125}$ I-fibrinogen (comparative control in Fig. 1, lower panel).

The concentration of platelets was an important factor in binding of ${ }^{125} \mathrm{I}-\mathrm{F}$. VIII $\mathrm{VWF}_{\mathrm{VWF}}$. At a low platelet concentration $\left(5 \times 10^{6}\right.$ cells), binding measured after a 60 -min incubation gave variable results, probably owing to poor recovery of platelets in the pellet. With 10 times more platelets $\left(5 \times 10^{7}\right.$ cells $)$, binding of ${ }^{125} \mathrm{I}$ $\mathrm{F}$. VIII $\mathrm{VWF}_{\mathrm{VW}}$ could be readily measured, and at $1.0 \times 10^{8}$ platelets $/ \mathrm{ml}$ (a concentration within the physiologic range), binding was optimal.

FIGURE 1 SDS polyacrylamide (5\%) gel electrophoresis of purified ${ }^{125} \mathrm{I}-\mathrm{F}$. VIII $\mathrm{VWF}_{\mathrm{VWF}}{ }^{125} \mathrm{I}-\mathrm{F}$. VIII $\mathrm{VWF}_{\mathrm{VWF}}$ was dissolved in $1 \%$ SDS with $1 \%$ dithiothreitol and was subject to disc gel electrophoresis as described in Methods. The gels were then stained with $0.1 \%$ Coomassie Brilliant Blue and cut into 1.5$\mathrm{mm}$ slices, which were counted for ${ }^{125} \mathrm{I}$. Recovery of the radioactivity applied to the gels was $>90 \%$. Upper panel: gel that contained only ${ }^{125} \mathrm{I}-\mathrm{F}$. VIII $\mathrm{VWF}_{\mathrm{VWF}}$. Middle panel: gel that contained ${ }^{125} \mathrm{I}$-labeled material bound to thrombin-stimulated platelets. Suspension of platelets $\left(1 \times 10^{8}\right.$ cells $)$ were treated with thrombin $(0.05 \mathrm{U})$ and incubated with ${ }^{125} \mathrm{I}-\mathrm{F}$. VIII $_{V W F}(8.2 \mu \mathrm{g})$ at $22^{\circ} \mathrm{C}$ for $60 \mathrm{~min}$. After sedimentation of the platelets through an oil mixture (Methods), the pelleted platelets were dissolved in 3\% SDS and $4 \mathrm{M}$ urea by heating at $100^{\circ} \mathrm{C}$ for $5 \mathrm{~min}$, and a portion of solubilized platelets was subjected to disc gel electrophoresis under reducing conditions as described in Methods. Distribution of ${ }^{125}$ I associated with thrombin-stimulated platelets corresponds to that of ${ }^{125} \mathrm{I}-\mathrm{F}$. VIII $\mathrm{VWF}_{\mathrm{VWF}}$ in the upper panel and does not correspond to the pattern of radioactivity distribution characteristic of ${ }^{125}$ I-fibrinogen run as comparative control (lower panel). Lower panel: gel that contained only purified ${ }^{125}$ I human fibrinogen labeled by the iodine monochloride method (20). 


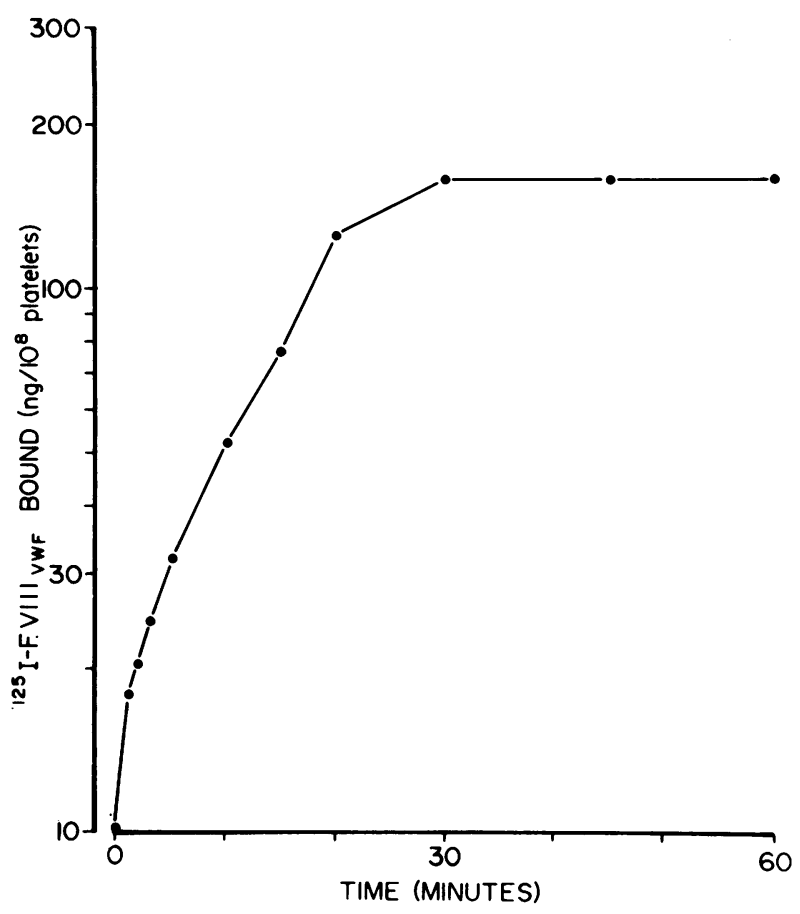

Figure 2 Time-course of ${ }^{125} \mathrm{I}-\mathrm{F}$. VIII $\mathrm{VWF}_{\mathrm{wF}}$ binding to human platelets induced by thrombin $(0.05 \mathrm{U} / \mathrm{ml})$. Ordinate: log scale of bound ${ }^{125} \mathrm{I}-\mathrm{F}$. VIII $\mathrm{VWF}_{\mathrm{VF}}$; abscissa: time in minutes. Platelets $\left(1 \times 10^{8}\right.$ cells $)$ were treated with thrombin for 3 min and then ${ }^{125} \mathrm{I}-\mathrm{F}$. VIII $\mathrm{VWF}_{\mathrm{VWF}}(0.8 \mu \mathrm{g})$ was added. At specified time intervals, platelets were rapidly centrifuged $(8,000 \mathrm{~g}$ for $2 \mathrm{~min}$ ) through an oil mixture to separate platelet-bound ligand from unbound material.

Binding of ${ }^{125} I-F$. VIII $I_{V W F}$ to metabolically intact platelets as compared with glutaraldehyde-fixed platelets. In these experiments, we compared the effect of thrombin on binding of F. VIII $\mathrm{VWF}_{\mathrm{VWF}}$ to metabolically intact platelets with that of glutaraldehydefixed platelets. Only intact platelets showed responsiveness to thrombin in terms of induction of binding of ${ }^{125} \mathrm{I}-\mathrm{F}$. VIII $\mathrm{VWF}_{\mathrm{VW}}$ (Fig. 4). In contrast to thrombin, ristocetin induced binding to both metabolically intact platelets and glutaraldehyde-treated platelets. The binding shown in Fig. 4 represents subsaturating conditions because the percentage of total added ${ }^{125} \mathrm{I}-\mathrm{F}$. VIII $_{\text {VwF }}$ that was bound increased upon addition of increasing concentrations of ${ }^{125} \mathrm{I}-\mathrm{F}$. VIII $\mathrm{VIWF}_{\mathrm{VW}}$.

Specificity of thrombin-induced binding. To establish the specificity of binding of ${ }^{125} \mathrm{I}-\mathrm{F}$. VIII $\mathrm{VWF}_{\mathrm{VWF}}$ to thrombin-treated platelets, the effect of a molar excess of unlabeled F. VIII ${ }_{V W F}$, fibrinogen, or fibronectin was examined. Although we did not detect these two proteins in our purified preparations of $\mathrm{F}$. VIII $_{\mathrm{VwF}}$ (see above), we checked whether the binding of ${ }^{125} \mathrm{I}-\mathrm{F}$. VIII $_{\mathrm{VWF}}$ is influenced by these two plasma proteins. A 100 -fold molar excess of fibrinogen or fibronectin did

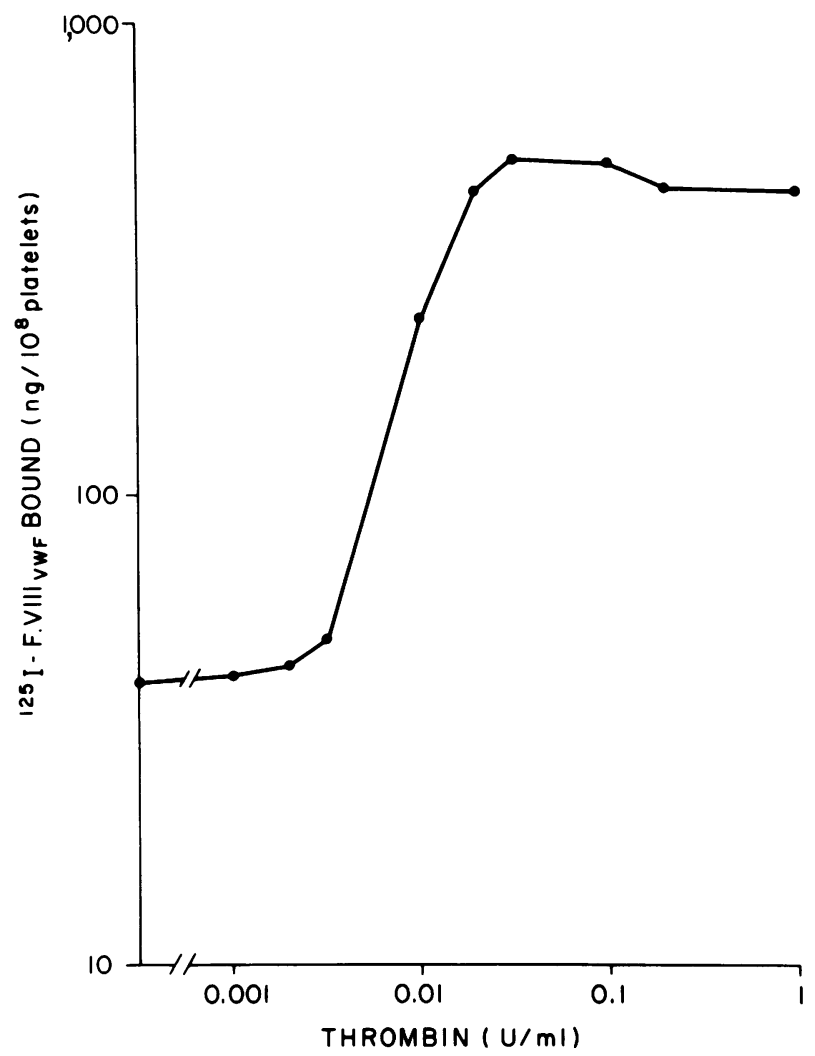

Figure 3 Binding of ${ }^{125} \mathrm{I}-\mathrm{F}$. VIII $\mathrm{vwF}_{\mathrm{vwF}}$ to human platelets stimulated with different concentrations of thrombin. Ordinate: log scale of bound ${ }^{125} \mathrm{I}-\mathrm{F}$. VIII ${ }_{\mathrm{VWF}}$; abscissa: thrombin concentration. Platelets $\left(1 \times 10^{8}\right.$ cells $)$ were treated with thrombin for $3 \mathrm{~min}$ and then $1.2 \mu \mathrm{g}$ of ${ }^{125} \mathrm{I}-\mathrm{F}$. VIII $\mathrm{VWF}$ was added to each tube.

not influence the binding of ${ }^{125} \mathrm{I}-\mathrm{F}$. $\mathrm{VIII}_{\mathrm{VWF}}$. On the other hand, the same molar excess of unlabeled $F$. VIII $_{\mathrm{VWF}}$ reduced the binding to $20 \%$ of the maximal value (Fig. 5).

Specificity of binding of ${ }^{125} \mathrm{I}-\mathrm{F}$. VIII $\mathrm{VwF}_{\mathrm{VWF}}$ to human platelets was further established using monospecific

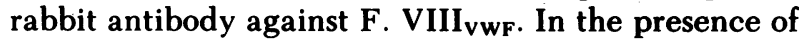
antibody, binding of ${ }^{125} \mathrm{I}-\mathrm{F}$. VIII $\mathrm{VWF}_{\mathrm{VWF}}$ to thrombin-stimulated platelets was reduced to $22 \%$ of the maximal value obtained in control samples. Similar inhibition was observed in a system containing ristocetin-treated platelets (results not shown).

Lack of thrombin-induced binding of ${ }^{125} I-F$. VIII $I_{V W F}$ after stripping off platelet membrane glycoproteins with chymotrypsin. Interaction of $\mathrm{F}$. VIII $\mathrm{VWF}_{\mathrm{VF}}$ with human platelets is related to the presence of Glycoprotein Ib on intact platelets (29). Congenital deficiency of this glycoprotein in Bernard-Soulier Syndrome, or its enzymatic removal with chymotrypsin reduces the interaction of $\mathrm{F}$. VIII $_{\mathrm{VWF}}$ with human platelets (30). Treatment of platelets with chymo- 


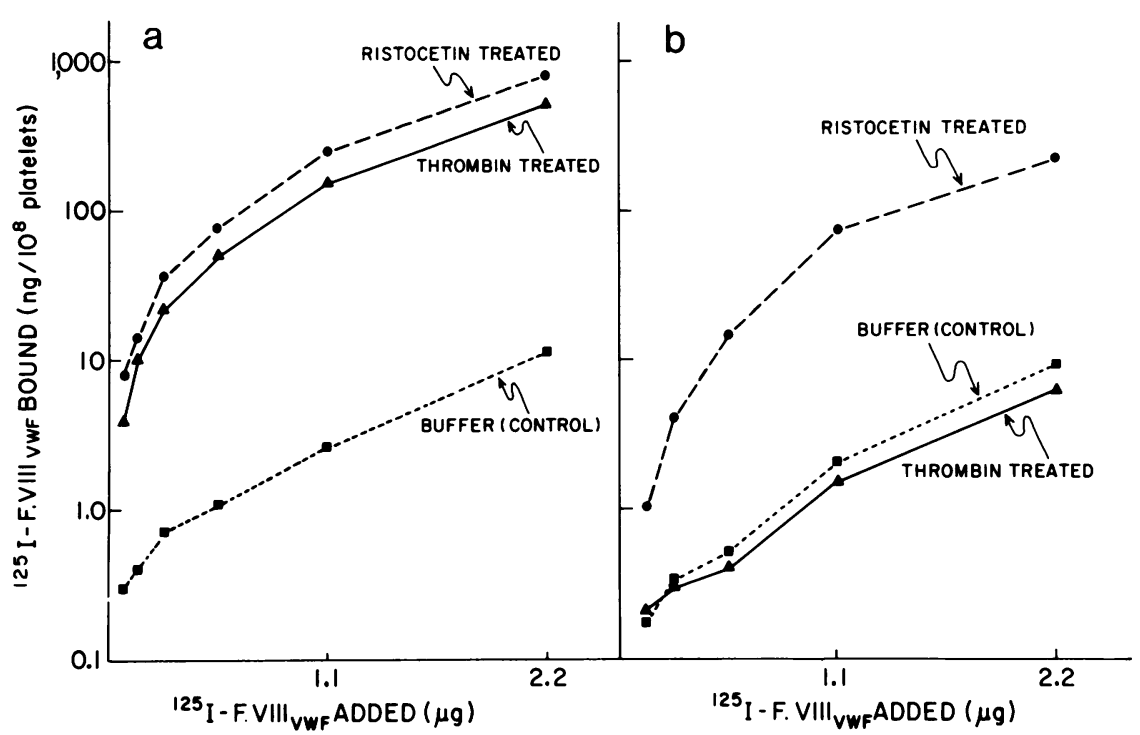

FIGURE 4 (a) Intact platelets, (b) glutaraldehyde-fixed platelets. Comparison of binding of ${ }^{125} \mathrm{I}-$

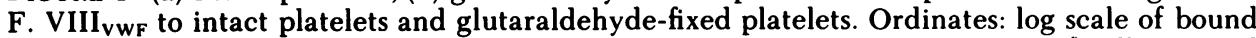
${ }^{125} \mathrm{I}-\mathrm{F}$. VIII $\mathrm{VWF}_{\mathrm{VF}}$; abscissa: total ${ }^{125} \mathrm{I}-\mathrm{F}$. VIII $\mathrm{VWF}_{\mathrm{W}}$ added to platelets. Platelets $\left(1 \times 10^{8}\right.$ cells $)$ treated with thrombin $(0.05 \mathrm{U} / \mathrm{ml})$ or ristocetin $(1 \mathrm{mg} / \mathrm{ml})$ were incubated with different concentrations of ${ }^{125} \mathrm{I}-\mathrm{F}$. VIII $\mathrm{VWF}_{\mathrm{VW}}$ for $60 \mathrm{~min}$ at room temperature without stirring.

trypsin $(300 \mu \mathrm{g} / \mathrm{m})$ reduced significantly the level of glycoprotein I complex as determined in SDS-PAGE of the solubilized platelet pellet obtained after chy-

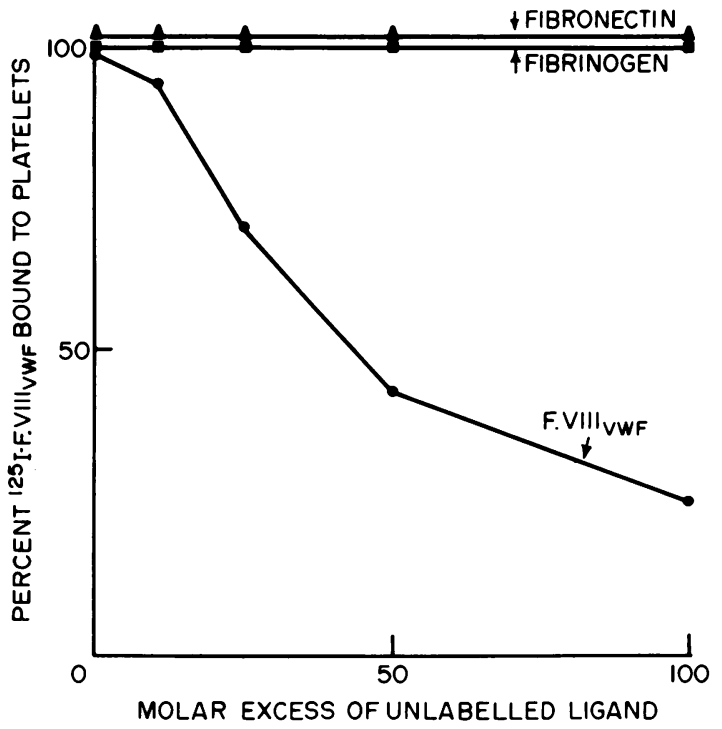

FIGURE 5 Inhibition of binding of ${ }^{125} \mathrm{I}-\mathrm{F}$. VIII $\mathrm{VWF}_{\mathrm{VW}}$ to human platelets by unlabeled F. VIII VwF $_{\text {as }}$ compared with fibrinogen and fibronectin. Platelets were treated with thrombin $(0.05 \mathrm{U} / \mathrm{ml})$ followed by hirudin $(0.2 \mathrm{U} / \mathrm{ml})$. Then unlabeled ligands at different concentrations were added with a constant amount of ${ }^{125} \mathrm{I}-\mathrm{F}$. VIII $\mathrm{VWF}_{\mathrm{F}}(0.22 \mu \mathrm{g})$. Molar concentrations were based on F. VIII VWF $_{\text {subunit }}\left(M_{r}=240,000\right)$. The $100 \%$ binding was $97 \mathrm{ng}{ }^{125} \mathrm{I}-\mathrm{F}$. VIII $\mathrm{VWF}_{\mathrm{VW}} / 10^{8}$ platelets as determined in the absence of unlabeled ligand. motrypsin treatment. Likewise, binding of ${ }^{125} \mathrm{I}-\mathrm{F}$. VIII $_{\mathrm{VWF}}$ to these platelets stimulated with thrombin or with ristocetin was reduced to negligible levels (results not shown).

Effect of chelators on thrombin-induced binding of ${ }^{125} I-F$. VIII $I_{V W F}$ to human platelets. Previous reports indicate that ristocetin-induced binding of $F$. VIII $_{\mathrm{VWF}}$ to human platelets was not inhibited by EDTA (9). Platelets used in those experiments were prepared by repeated centrifugation and washing using EDTAcontaining Tris buffer. To compare our system based on thrombin-stimulated binding with that based on ristocetin-induced binding, we examined the effect of the different methods of preparing platelets on binding of F. VIII $\mathrm{VWF}_{\mathrm{FF}}$ stimulated by thrombin and by ristocetin. In method 1 , which was based on stepwise albumin gradient and gel filtration (15) both thrombin and ristocetin induced the binding of ${ }^{125} \mathrm{I}-\mathrm{F}$. VIII $\mathrm{VWF}_{\mathrm{VWF}}$ to platelets (Fig. 6). In method 2, based on the washing of platelets with EDTA-containing Tris buffer (9), the binding of ${ }^{125} \mathrm{I}-\mathrm{F}$. VIII $\mathrm{VWF}_{\mathrm{VWF}}$ to platelets was induced by ristocetin, which gave almost identical concentrationdependent curves as with platelets prepared by method 1. However, thrombin treatment of platelets prepared by method 2 did not induce binding of ${ }^{125} \mathrm{I}-\mathrm{F}$. VIII $\mathrm{VWF}_{\mathrm{VWF}}$ to platelets. Addition of $\mathrm{CaCl}_{2}(2 \mathrm{mM})$ to the incubation mixture restored the binding reactivity of thrombin-treated platelets prepared by method 2 . Because of the lack of thrombin-induced binding to platelets prepared by washing with buffer containing EDTA, the effect of chelators was examined. Both 


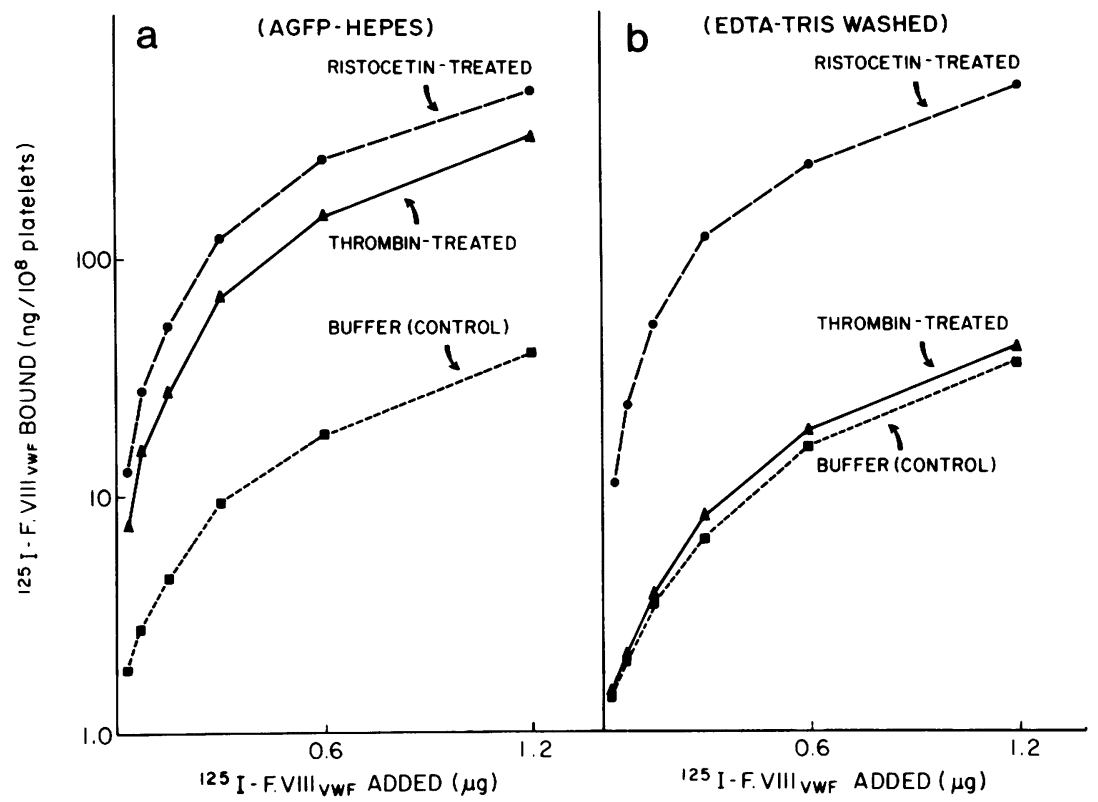

Figure 6 (a) Platelets prepared by method 1, (b) platelets prepared by method 2. Comparison of binding of ${ }^{125} \mathrm{I}-\mathrm{F}$. VIII $\mathrm{VWF}_{\mathrm{V}}$ to human platelets prepared by method 1 (albumin gradient-gel filtration) and method 2 (EDTA-Tris buffer washing). Ordinate: log scale of bound ${ }^{125}$ I-F. VIII $_{\mathrm{VWF}}$; abscissa: total ${ }^{125} \mathrm{I}-\mathrm{F}$. VIII $\mathrm{VWF}_{\mathrm{VW}}$ added to platelets. Platelets were treated with thrombin $(0.05 \mathrm{U} / \mathrm{ml})$ or ristocetin $(1 \mathrm{mg} / \mathrm{ml})$ and binding of different concentrations ${ }^{125} \mathrm{I}-\mathrm{F}$. VIII $\mathrm{VWF}_{\mathrm{VW}}$ was determined.

EDTA (2 $\mathrm{mM})$ and EGTA (2 $\mathrm{mM})$ added to platelets prepared by method 1 inhibited thrombin-induced binding of ${ }^{125} \mathrm{I}-\mathrm{F}$. VIII $\mathrm{VWF}_{\mathrm{VW}}$ by 92 and $90 \%$, respectively. Inhibition was observed when chelators were added $5 \mathrm{~min}$ before thrombin or $8 \mathrm{~min}$ after thrombin. These chelators did not inhibit thrombin-induced release of $\left[{ }^{3} \mathrm{H}\right]$ serotonin from platelets prepared by method 1 , thus indicating that they are affecting receptor interaction with $F$. VIII ${ }_{V W F}$ rather than thrombin binding and subsequent activation of platelets.

Prostacyclin inhibition of binding of ${ }^{125} I-F$. VIII $I_{V W F}$ to thrombin-activated platelets. In these experiments, we examined whether prostacyclin inhibits the process of $F$. VIII ${ }_{\mathrm{VWF}}$ receptor exposure by thrombin and ristocetin. Prostacyclin inhibited, in a concentration-dependent manner, binding of ${ }^{125} \mathrm{I}-\mathrm{F}$. VIII $\mathrm{VWF}_{\mathrm{VWF}}$ to human platelets induced by low thrombin concentration $\left(0.01 \mathrm{U} / \mathrm{ml}\right.$ ) (Fig. 7). On the other hand, $\mathrm{PGI}_{2}$ was not inhibitory toward binding of ${ }^{125} \mathrm{I}-\mathrm{F}$. VIII $_{\mathrm{VWF}}$ to human platelets treated with ristocetin. Although $\mathbf{P G I}_{2}$ was inhibitory at the concentration range $1-10 \mathrm{nM}$, the inhibition by 6 keto $\mathrm{PGF}_{1 \alpha}$ was not observed at 1 $\mathrm{nM}$ and only $24 \%$ binding was inhibited at $10 \mathrm{nM}$. This effect of 6 keto $\mathrm{PGF}_{1 \alpha}$ represented $\sim 2 \%$ of the inhibitory potency of $\mathbf{P G I}_{2}$.

The effects of time of addition of $\mathrm{PGI}_{2}$ on inhibition of binding of ${ }^{125 I-F}$. VIII ${ }_{\mathrm{VWF}}$ to human plate- lets. To distinguish between the two possible modes of action of prostacyclin on the interaction of $F$. VIII $_{\mathrm{VWF}}$ with human platelets, i.e., the effect of $\mathrm{PGI}_{2}$ on the process of receptor induction by thrombin, and the effect of $\mathrm{PGI}_{2}$ on the already formed ligand-receptor complex, the following experiments were conducted. $\mathrm{PGI}_{2}$ was added to platelets at different stages of thrombin-platelet and platelet- ${ }^{125} I-F$. VIII ${ }_{\mathrm{VWF}}$ interactions.

In the first experiments, $\mathrm{PGI}_{2}$ was added to human platelets $3 \mathrm{~min}$ before addition of thrombin, which was followed 8 min later by addition of ${ }^{125} \mathrm{I}-\mathrm{F}$. VIII $\mathrm{VWF}_{\mathrm{VWF}}$. A concentration-dependent inhibition of ${ }^{125} \mathrm{I}-\mathrm{F}$. VIII $\mathrm{VWWF}_{\mathrm{VWF}}$ binding by $\mathrm{PGI}_{2}$ was observed as shown in Fig. 7. Addition of $\mathrm{PGI}_{2} 10 \mathrm{~min}$ before thrombin $(0.01 \mathrm{U} / \mathrm{ml})$ did not change the inhibitory effect of this prostaglandin. A more striking effect of the prostacyclin action was noted when prostacyclin was added following thrombin and ${ }^{125} \mathrm{I}-\mathrm{F}$. VIII $\mathrm{VwF}_{\mathrm{vw}}$. Whether $\mathrm{PGI}_{2}$ was added 3,10 , or even $30 \mathrm{~min}$ after, the effect was the same, namely inhibition of binding of ${ }^{125} \mathrm{I}-\mathrm{F}$. VIII $\mathrm{VWF}_{\mathrm{VWF}}$ by the same range of prostacyclin concentrations.

The effect of $\mathrm{PGI}_{2}$ added to platelets after ${ }^{125} \mathrm{I}-\mathrm{F}$. VIII $_{V W F}$ was investigated in more detail by following the time-course of binding (Fig. 8). When binding reached equilibrium at $30 \mathrm{~min}$ after addition of ${ }^{125} \mathrm{I}$ F. VIII $_{\mathrm{VWF}}$, prostacyclin (a concentration of $50 \mathrm{nM}$ ), 


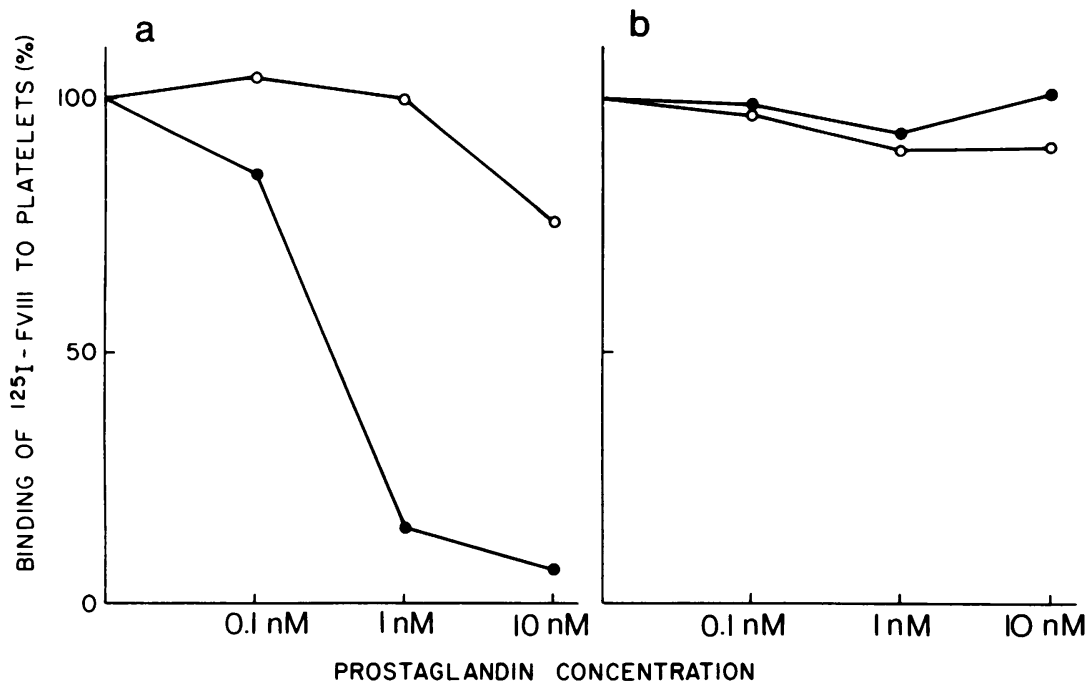

Figure 7 (a) Thrombin-treated platelets, (b) ristocetin-treated platelets. The effect of prostacyclin (solid circles) and 6 keto PGF $_{1 \alpha}$ (open circles) on binding of ${ }^{125}$ I-F. VIII $\mathrm{VWF}_{\mathrm{w}}$ to human platelets. Platelets $\left(1 \times 10^{8}\right.$ cells $)$ were treated with different concentrations of prostaglandins for $3 \mathrm{~min}$, followed by addition of thrombin $(0.01 \mathrm{U} / \mathrm{ml})$ or ristocetin $(1 \mathrm{mg} / \mathrm{ml})$. After $3 \mathrm{~min}$, free thrombin was inactivated by hirudin $(0.04 \mathrm{U} / \mathrm{ml})$ and then $0.34 \mu \mathrm{g}$ of ${ }^{125} \mathrm{I}-\mathrm{F}$. VIII $\mathrm{VwF}_{\mathrm{vas}}$ added to each tube. Binding was determined after $60 \mathrm{~min}$ incubation at room temperature without stirring. Binding of ${ }^{125} \mathrm{I}-\mathrm{F}$. VIII $\mathrm{VWF}_{\mathrm{vw}}$ to platelets pretreated with Tris buffer, pH 9.37 (diluent for $\mathrm{PGI}_{2}$ and 6 keto $\mathrm{PGF}_{1 \alpha}$ ), was accepted as $100 \%$.

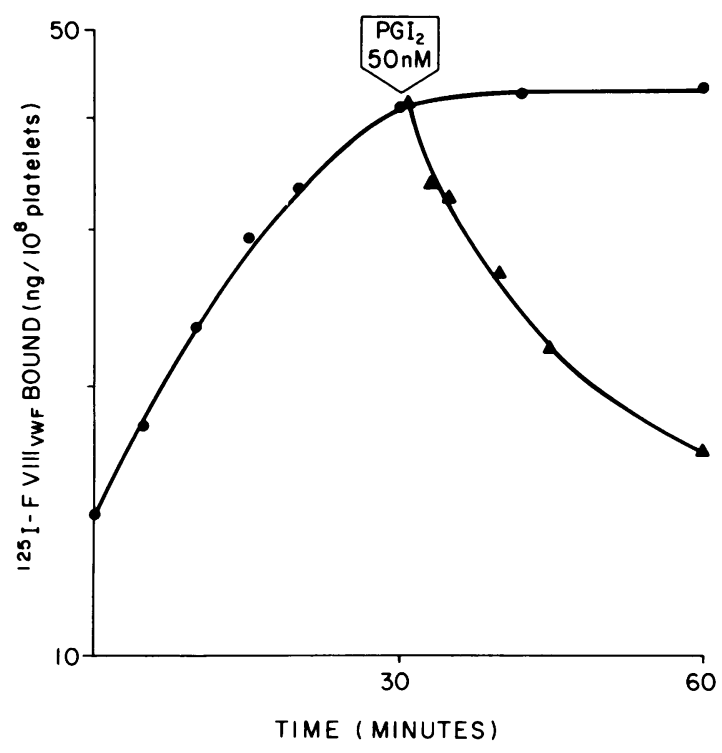

Figure 8 Reversal of binding of ${ }^{125} \mathrm{I}-\mathrm{F}$. VIII $\mathrm{VwF}_{\mathrm{wF}}$ to human platelets by prostacyclin. Ordinate: log scale of bound ${ }^{125} \mathrm{I}$ F. VIII ${ }_{\mathrm{VWF}}$; abscissa: time in minutes. Platelets $\left(1 \times 10^{8}\right.$ cells $)$ were treated with thrombin $(0.01 \mathrm{U} / \mathrm{ml})$ for $3 \mathrm{~min}$ followed by hirudin $(0.02 \mathrm{U} / \mathrm{ml})$ for $2 \mathrm{~min}$ and then ${ }^{125} \mathrm{I}-\mathrm{F}$. VIII $\mathrm{VWF}_{\mathrm{VWF}}$ $(0.38 \mu \mathrm{g})$ was added. The time-course of binding was determined. The solid circles represent binding to platelets treated with thrombin and Tris buffer, $\mathrm{pH} 9.37$; solid triangles show the reversal of binding following addition of 50 $n \mathrm{M} \mathrm{PGI}_{2}$ to a parallel portion of the reaction mixture. was added to one of two sets of tubes containing the incubation mixture. Tris buffer, pH 9.37, was added to the other set, which served as a positive control for binding. After addition of $\mathrm{PGI}_{2}$ there was a gradual dissociation of bound ${ }^{125} \mathrm{I}-\mathrm{F}$. VIII $\mathrm{VWF}_{\mathrm{VW}}$, indicating that prostacyclin is able to reverse binding of ${ }^{125} \mathrm{I}-\mathrm{F}$. VIII $_{\mathrm{VWF}}$, which had already attained equilibrium.

Inhibitory effect of $P G I_{2}$ on binding of ${ }^{125} I-F$. $V I I I_{V W F}$ is mimicked by dcAMP. PGI $_{2}$ is the most potent activator of platelet adenylate cyclase known to date $(31,32)$. Therefore, its inhibitory effect on the binding of ${ }^{125} \mathrm{I}-\mathrm{F}$. VIII $\mathrm{VWF}_{\mathrm{VF}}$ can be mediated by cAMP, which is generated as a result of $\mathbf{P G I}_{2}$ action. To examine this possibility, we performed a series of experiments in which $\mathbf{P G I}_{2}$ was substituted with dcAMP. We have observed a concentration-dependent inhibition of binding by dcAMP (Fig. 9). Again, like $\mathbf{P G I}_{2}$, dcAMP was added at different stages in regard to the binding process. Addition of dcAMP $5 \mathrm{~min}$ before thrombin, i.e., 10 min before ${ }^{125 I-F}$. VIII ${ }_{\text {vwF }}$ (curve A), 5 min after thrombin, i.e., simultaneously with ${ }^{125} \mathrm{I}-\mathrm{F}$. VIII $_{\mathrm{VWF}}$ (curve B), 8 min after thrombin (curve C), or 35 min after thrombin, i.e., 30 min after ${ }^{125}$ I-F. VIII ${ }_{V W F}$ (curve D), resulted in concentration-dependent inhibition of binding. Although the effect of dcAMP added 30 min after ${ }^{125} \mathrm{I}-\mathrm{F}$. VIII $\mathrm{VWF}_{\mathrm{VW}}$ was less pronounced, it still caused a $50 \%$ reversal of binding at a concentration of $0.3 \mathrm{mM}$ of dcAMP. 


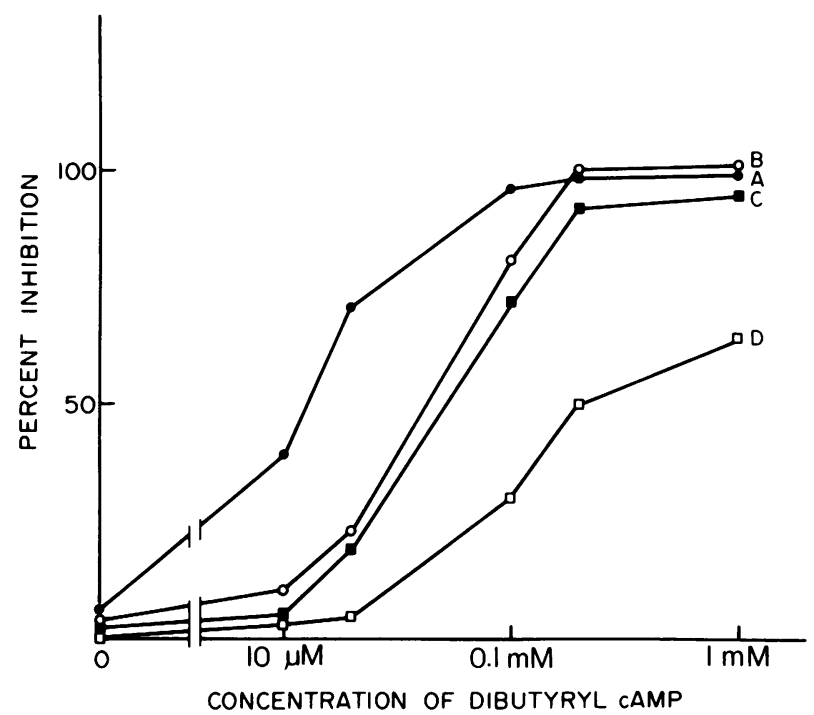

FIGURE 9 Inhibition of binding of ${ }^{125} \mathrm{I}-\mathrm{F}$. VIII $\mathrm{VWF}_{\mathrm{WF}}$ to human platelets by dcAMP added to platelets at different times in reference to the addition of thrombin $(0.01 \mathrm{U} / \mathrm{ml})$. In each instance, platelets were treated with thrombin and with hirudin before the addition of ${ }^{125} \mathrm{I}-\mathrm{F}$. VIII $\mathrm{VWF}_{\mathrm{VWF}}(0.4 \mu \mathrm{g}) . \mathrm{A}$, dcAMP $5 \mathrm{~min}$ before thrombin. B, dcAMP 5 min after thrombin. C, dcAMP $8 \mathrm{~min}$ after thrombin. D, dcAMP $30 \mathrm{~min}$ after ${ }^{125} \mathrm{I}-\mathrm{F}$. VIII $\mathrm{VWF}$ (35 min after thrombin).

\section{DISCUSSION}

Our results indicate that in intact platelets thrombin induces binding of $\mathrm{F}$. VIII $\mathrm{VWF}_{\mathrm{VWF}}$ to a specific membrane receptor. The specificity of the interaction between $F$. VIII $_{\mathrm{VWF}}$ and human platelets is based on the following evidence. By following the additional step of immunoaffinity chromatography with monospecific antihuman fibrinogen IgG, we obtained F. VIII VwF $_{\text {prep- }}$ arations essentially devoid of another plasma protein, fibrinogen. Fibrinogen interacts with a distinct receptor on platelets stimulated with thrombin (33). Furthermore, thrombin-induced binding of ${ }^{125} \mathrm{I}-\mathrm{F}$. VIII $\mathrm{VWF}_{\mathrm{VW}}$ was specific because it was not inhibited by 100 -fold molar excess of either fibrinogen or fibronectin, but was inhibited by an excess of unlabeled, purified $\mathrm{F}$. VIII $_{\mathrm{VWF}}$ and by monospecific rabbit antibody against human F. VIII. Binding of F. VIII ${ }_{\mathrm{VWF}}$ to human platelets in our system was induced by a very low concentration of thrombin (0.1-0.5 $\mathrm{nM}$ ), which can be generated physiologically (11). Such low concentrations of thrombin exert a direct effect on platelets to induce the exposure of specific receptors for F. VIII ${ }_{V W F}$, rather than to induce changes in $\mathrm{F}$. VIII $_{\mathrm{VWF}}$ promoting its subsequent interaction with intact platelets. Preincubation of thrombin with ${ }^{125} \mathrm{I}-\mathrm{F}$. VIII $\mathrm{VWF}_{\mathrm{VWF}}$ remained without a measurable effect on the interaction of this complex with unstimulated platelets.

Comparison of the binding of F. VIII ${ }_{\mathrm{VWF}}$ to platelets stimulated with thrombin with that of platelets treated with ristocetin has demonstrated several hitherto unrecognized aspects of this interaction. Although the extent of binding induced by thrombin at low concentrations $(0.5 \mathrm{nM}$ or $0.05 \mathrm{U} / \mathrm{ml})$ is similar to that of ristocetin, the process of exposure of the $\mathrm{F}$. VIII $_{\mathrm{VWF}}$ receptor by thrombin and ristocetin is different. Induction of $\mathrm{F}$. VIII $\mathrm{VWF}_{\mathrm{VF}}$ binding by thrombin requires metabolically intact platelets and is sensitive to EDTA and EGTA. The thrombin-induced receptor is inhibited by prostacyclin. Ristocetin-induced binding does not require metabolically active platelets, is not sensitive to chelators $(9,10)$, and is not sensitive to inhibition by prostacyclin. Thus, it appears that the receptor for F. VIII $\mathrm{VWF}_{\mathrm{VF}}$ can be induced in human platelets through two different mechanisms.

Binding of F. VIII ${ }_{V W F}$ to its platelet receptor, induced by thrombin, represents one of a few examples of receptor induction by this proteolytic enzyme. Previously, it was demonstrated that thrombin induces binding of Factor $\mathrm{Xa}$ to human platelets through mobilization of platelet Factor V (34). Also, thrombin caused a marked increase in, and redistribution of, the platelet receptor for lentil phytohemagglutinin (35). Recently, we have shown that thrombin induces binding of fibrinogen to the human platelet receptor (33). It appears that thrombin interacts with membrane mechanism(s) in human platelets, which results in exposure of membrane receptors for a number of different ligands. It was established that in the case of Factor Xa binding, this thrombin-dependent mechanism required the release reaction (34). The effect of thrombin does not appear to involve stimulation of $d e$ novo receptor formation because the protein synthesis in platelets is very limited (36). Furthermore, the receptor for $\mathrm{F}$. VIII VWF $_{\mathrm{VW}}$ appears to be present in platelets because membranes prepared from disrupted platelets are able to bind plasma F. VIII VWF $_{\text {(3) }}$ (37).

The thrombin-sensitive membrane component(s) responsible for exposure of the receptor for F. VIII $\mathrm{VWF}_{\mathrm{WF}}$ is apparently of restricted sensitivity because other proteolytic enzymes, such as cymotrypsin, not only do not induce binding of F. VIII $\mathrm{VWF}_{\mathrm{VW}}$ to platelets (in striking contrast to fibrinogen binding, e.g., ref. 38), but also make them refractory to subsequent receptor exposure by thrombin or ristocetin. The platelet membrane glycoprotein of $M_{r} 68,000-85,000$ (Glycoprotein $\mathrm{V})$, has been proposed as the thrombin substrate in intact platelets $(39,40)$. Whether this glycoprotein is linked to Glycoprotein $\mathrm{Ib}$ or to some other mechanism(s) controlling the availability of F. VIII ${ }_{V w F}$ receptors remains to be examined.

Calcium is required for the binding of $\mathrm{F}$. VIII $_{\mathrm{VWF}}$ to platelets because EDTA used while platelets are washed prevents binding, and EDTA added to platelets before thrombin, or even $8 \mathrm{~min}$ after thrombin, 
inhibits binding of F. VIII $\mathrm{VWF}_{\mathrm{VF}}$. This is in all likelihood the main reason why platelets washed with an EDTAcontaining buffer (9), which we used in method 2 of platelet separation, did not bind F. VIII $\mathrm{VWF}_{\mathrm{F}}$ in response to thrombin. It is possible that EDTA removes from the platelet membrane the surface-bound calcium essential for formation of a complex between $\mathrm{F}$. VIII $\mathrm{VWF}_{\mathrm{VWF}}$ and its receptor.

The mechanism of inhibition of binding of ${ }^{125} \mathrm{I}-\mathrm{F}$. VIII $_{V W F}$ to human platelets by $\mathrm{PGI}_{2}$ seems to be dependent on cAMP, because dcAMP can cause a similar inhibition of binding. Therefore, this mechanism can be related to several platelet reactions that are influenced by cAMP, such as phosphorylation of platelet proteins (41) and inhibition of calcium flux (42). The receptor for $\mathrm{F}$. VIII $\mathrm{VWF}_{\mathrm{W}}$ is induced by thrombin, which is known to inhibit adenylate cyclase in platelets (43). The inhibition of adenylate cyclase by thrombin appears to be reversible because $\mathbf{P G I}_{2}$ is able to obviate this effect of thrombin. The availability of divalent cations is a prerequisite for $\mathrm{F}$. VIII $\mathrm{VWF}_{\mathrm{vw}}$ binding to its receptor on thrombin-stimulated platelets. The known inhibitory effect of cAMP on calcium mobilization (42) may thus contribute to inhibition of thrombin-induced binding of F. VIII $\mathrm{VWF}_{\mathrm{VW}}$ by prostacyclin. The dissociation of bound $\mathrm{F}$. VIII ${ }_{\mathrm{VWF}}$ from its receptor by $\mathrm{PGI}_{2}$ indicates that this ligand is not internalized by platelets, at least during the first $30 \mathrm{~min}$ of interaction.

Dual regulation of the platelet receptor for $F$. VIII $_{\mathrm{VWF}}$ by $\mathrm{PGI}_{2}$, as described herein, provides the mechanism that may explain the known inhibitory effect of prostacyclin on formation of platelet aggregates, due to platelet spreading, on the subendothelial layer of the aorta and the inhibition of platelet thrombus formation $(44,45)$ because both phenomena require F. VIII $I_{\mathrm{VWF}}(46)$. The inhibitory effect of $\mathrm{PGI}_{2}$ is not limited to the receptor for $\mathrm{F}$. VIII $\mathrm{VWF}_{\mathrm{VWF}}$ on human platelets. The receptor for fibrinogen (33) and the receptor for the $\mathrm{Fc}$ fragment of IgG are also regulated by $\mathrm{PGI}_{2}$ (47).

Our results provide evidence that the proteolytic enzyme thrombin induces exposure of a specific receptor for $\mathrm{VIII}_{\mathrm{VWF}}$ in human platelets and that prostacyclin can prevent this process. Analysis of thrombin-induced membrane changes governing platelet receptor exposure for $\mathrm{F}$. VIII $\mathrm{VWF}_{\mathrm{VW}}$ as presented in this study can facilitate a search for the initial signal for platelet binding of F. VIII $\mathrm{VWF}_{\mathrm{VW}}$ in vivo.

\section{ACKNOWLEDGMENTS}

We wish to thank Dr. Mark Weinstein (Boston Veterans Administration Medical Center, Boston, MA) and Dr. Marek Kloczewiak (Vanderbilt University, Nashville, TN) for helpful discussions. We are indebted to Dr. Toyohiko Ariga (Vanderbilt University, Nashville, TN) for performance of radioimmunoassay of human fibrinogen in $F$. VIII ${ }_{V W F}$ preparations. We are also indebted to Dr. John Fenton III, New York Department of Public Health, Albany, NY, and Dr. Leon Cunningham, Vanderbilt University, Nashville, TN, for sharing with us purified human $\alpha$-thrombin preparation, and to Dr. John Pike, Upjohn Co., Kalamazoo, MI, for providing $\mathrm{PGI}_{2}$ and 6 -keto $\mathrm{PGF}_{1 \alpha}$.

This work was supported by research grants from the U.S. Public Health Service National Institutes of Health: HL25935, HL-27560, and HL-25107.

\section{REFERENCES}

1. Sixma, J. J., and J. Webster. 1977. The hemostatic plug. Semin. Hematol. 14: 265-299.

2. Hoyer, L. W. 1976. Von Willebrand's Disease. In Progress in Hemostasis and Thrombosis. T. Spaet, editor. Grune \& Stratton, Inc., New York. 3: 231-287.

3. Cazenave, J. P., M. A. Packham, R. L. Kinlough-Rathbone, and J. F. Mustard. 1978. Platelet adherence to the vessel wall and collagen-coated surfaces. Adv. Exp. Med. Biol. 102: 31-47.

4. Weiss, H. J., L. W. Hoyer, F. R. Rickles, A. Varma, and J. Rogers. 1973. Quantitative assay of a plasma factor deficient in von Willebrand Disease that is necessary for platelet aggregation. Relationship to Factor VIII procoagulant activity and antigen content. J. Clin. Invest. 52: 2708-2716.

5. Zucker, M. B., S. J. Kim, J. McPherson, and R. A. Grant. 1977. Binding of Factor VIII to platelets in the presence of ristocetin. Br. J. Haematol. 35: 535-549.

6. Schneider-Trip, M. D., C. S. P. Jenkins, L. H. Kahle, A. Sturk, and J. W. ten Cate. 1979. Studies on the mechanism of ristocetin-induced platelet aggregation. Binding of Factor VIII to platelets. Br. J. Haematol. 43: 99112.

7. Jenkins, C. S. P., K. J. Clemetsen, and E. F. Lüscher. 1979. Studies on the mechanism of ristocetin-induced platelet aggregation. Binding of ristocetin to platelets. J. Lab. Clin. Med. 93: 220-231.

8. Morisato, D. K., and H. R. Gralnick. 1980. Selective binding of the Factor VIII/von Willebrand Factor protein to human platelets. Blood. 55: 9-15.

9. Kao, K. J., S. V. Pizzo, and P. A. McKee. 1979. Demonstration and characterization of specific binding sites for Factor VIII/von Willebrand Factor on human platelets. J. Clin. Invest. 63: 656-664.

10. Kao, K. J., S. V. Pizzo, and P. A. McKee. 1979. Platelet receptors for human Factor VIII/von Willebrand protein. Functional correlation of receptor occupancy and ristocetin-induced platelet aggregation. Proc. Natl. Acad. Sci. U. S. A. 76: 5317-5320.

11. Shuman, M. A., and P. W. Majerus. 1976. The measurement of thrombin in clotting blood by radioimmunoassay. J. Clin. Invest. 58: 1249-1258.

12. Nossel, H. L., M. Ti, K. L. Kaplan, K. Spanondis, T. Soland, and V. P. Butler, Jr. 1976. The generation of fibrinopeptide $A$ in clinical blood samples. Evidence for thrombin activity. J. Clin. Invest. 58: 1136-1144.

13. Gryglewski, R. J., S. Bunting, S. Moncada, R. J. Flower, and J. R. Vane. 1976. Arterial walls are protected against deposition of platelet thrombi by a substance (Prostaglandin $\mathrm{X}$ ) which they make from prostaglandin endoperoxides. Prostaglandins. 12: 685-713.

14. Weksler, B. B., A. J. Marcus, and E. A. Jaffe. 1977. Synthesis of prostaglandin $\mathrm{I}_{2}$ (prostacyclin) by cultured human and bovine endothelial cells. Proc. Natl. Acad. Sci. U. S. A. 74: 3922-3926. 
15. Timmons, S., and J. Hawiger. 1978. Separation of human platelets from plasma proteins including $\mathrm{F}$. VIII VWF $_{\mathrm{VW}}$ a combined albumin gradient-gel filtration method using HEPES buffer. Thromb. Res. 12: 297-306.

16. Pfueller, S. L., S. Weber, and E. F. Lüsher. 1977. Studies of the mechanism of the human platelet release reaction induced by immunologic stimuli. III. Relationship between the binding of soluble IgG aggregates to the Fc receptor and cell response in the presence and absence of plasma. J. Immunol. 118: 514-524.

17. Hawiger, J., S. Steckley, D. Hammond, C. Cheng, S. Timmons, A. D. Glick, and R. M. Des Prez. 1979. Staphylococci-induced human platelet injury mediated by Protein A and immunoglobulin G Fc fragment receptor. J. Clin. Invest. 64: 931-937.

18. Sodetz, J. M., S. V. Pizzo, and P. A. McKee. 1977. Relationship of sialic acid to function and in vivo survival of human factor VIII/von Willebrand factor protein. $J$. Biol. Chem. 252: 5538-5546.

19. Engvall, E., and E. Ruoslahti. 1977. Binding of soluble form of fibroblast surface protein, fibronectin to collagen. Int. J. Cancer. 20: 1-5.

20. McFarlane, A. S. 1963. In vivo behavior of $\mathrm{I}^{131}$-fibrinogen. J. Clin. Invest. 42: 346-361.

21. Martin, B. M., W. W. Wasiewski, J. W. Fenton III, and T. C. Detwiler. 1976. Equilibrium binding of thrombin to platelets. Biochemistry. 15: 4886-4893.

22. Lipinska, I., B. Lipinski, and V. Gurewich. 1974. Fibrinogen heterogeneity in human plasma. Electrophoretic demonstration and characterization of two major fibrinogen components. J. Lab. Clin. Med. 84: 509-516.

23. Tollefsen, D. M., and P. W. Majerus. 1975. Inhibition of human platelet aggregation by monovalent anti-fibrinogen antibody fragments. J. Clin. Invest. 55: 12591268

24. Weber, K., and M. Osborn. 1969. The reliability of molecular weight determination by dodecyl sulfate-polyacrylamide gel electrophoresis. J. Biol. Chem. 244: 4406-4412.

25. Lowry, O. H., N. J. Rosebrough, A. L. Farr, and R. L. Randall. 1951. Protein measurement with the Folin phenol reagent. J. Biol. Chem. 193: 265-275.

26. Hawiger, J., S. Niewiarowski, V. Gurewich, and D. P. Thomas. 1970. Measurement of fibrinogen and fibrin degradation products in serum by staphylococcal clumping test. J. Lab. Clin. Med. 75: 93-108.

27. Ouchterlony, O. 1958. Diffusion-in-gel methods for immunological analysis. In Progress in Allergy. P. Kallos, editor. Karger, Basel. 5: 1-78.

28. Weinstein, M., and D. Deykin. 1979. Comparison of Factor VIII-related von Willebrand Factor proteins prepared from human cryoprecipitate and Factor VIII concentrate. Blood. 53: 1095-1105.

29. Nachman, R. L., E. A. Jaffe, and B. B. Weksler. 1977. Immuno-inhibition of ristocetin-induced platelet aggregation. J. Clin. Invest. 59: 143-148.

30. Jenkins, C. S. P., D. R. Phillips, K. J. Clementson, D. Meyer, M-J. Larrieu, and E. F. Lüscher. 1976. Platelet membrane glycoproteins implicated in ristocetin-induced aggregation. Studies of the proteins on platelets from patients with Bernard-Soulier syndrome and von Willebrand's disease. J. Clin. Invest. 57: 112-124.
31. Gorman, R. R., S. Bunting, and O. V. Miller. 1977. Modulation of human platelet adenylate cyclase by prostacyclin (PGX). Prostaglandins. 13: 377-388.

32. Best, L. C., T. J. Martin, R. G. G. Russell, and F. E. Preston. 1977. Prostacyclin increases cyclic AMP levels and adenylate cyclase activity in platelets. Nature (Lond.). 267: 850-853.

33. Hawiger, J., S. Parkinson, and S. Timmons. 1980. Prostacyclin inhibits mobilization of fibrinogen-binding sites on human ADP- and thrombin-treated platelets. Nature (Lond.). 283: 195-197.

34. Miletich, J. P., C. M. Jackson, and P. W. Majerus. 1977. Interaction of coagulation Factor Xa with human platelets. Proc. Natl. Acad. Sci. U. S. A. 74: 4033-4036.

35. Feagler, J. R., T. W. Tillack, D. D. Chaplin, and P. W. Majerus. 1974. The effects of thrombin on phytohemagglutinin receptor sites in human platelets. J. Cell Biol. 60: 541-553.

36. Karpatkin, S. 1969. Heterogeneity of human platelets 1. Metabolic and kinetic evidence suggestive of young and old platelets. J. Clin. Invest. 48: 1084-1087.

37. Koutts, J., and T. S. Zimmerman. 1978. Human Factor VIII antigen binding to platelet membranes: correlation of size and function. Clin. Res. 26: 350A.

38. Niewiarowski, S., A. Z. Budzynski, T. A. Morinelli, T. M. Brudzynski, and G. J. Stewart. 1981. Exposure of fibrinogen receptor on human platelets by proteolytic enzymes. J. Biol. Chem. 256: 917-925.

39. Phillips, D. A., and P. P. Agin. 1977. Platelet plasma membrane glycoproteins. Identification of a proteolytic substrate for thrombin. Biochem. Biophys. Res. Commun. 75: 940-947.

40. Mosher, D. F., A. Vaheri, J. J. Choate, and C. G. Gahmberg. 1979. Action of thrombin on surface glycoproteins of human platelets. Blood. 53: 437-445.

41. Haslam, R. J., M. M. L. Davidson, J. E. B. Fox, and J. A. Lynham. 1978. Cyclic nucleotides in platelet function. Thromb. Haemostasis. 40: 232-240.

42. Kaser-Glanzmann, R., J. Jakabova, J. N. George, and E. F. Lüsher. 1977. Stimulation of calcium uptake in platelet membrane vesicles by adenosine $3^{\prime}, 5^{\prime}$-cyclic monophosphate and protein kinase. Biochim. Biophys. Acta. 466: 429-440.

43. Brodie, G. N., N. L. Baenzinger, L. R. Chase, and P. W. Majerus. 1973. The effects of thrombin on adenyl cyclase activity and a membrane protein from human platelets. J. Clin. Invest. 51: 81-88.

44. Weiss, H. J., and V. T. Turitto. 1979. Prostacyclin (Prostaglandin $\mathrm{I}_{2}, \mathrm{PGI}_{2}$ ) inhibits platelet adhesion and thrombus formation on subendothelium. Blood. 53: 244-250.

45. Gryglewski, R. J., R. Korbut, and A. Ocetkiewicz. 1978 Generation of prostacyclin by lungs in vivo and its release into the arterial circulation. Nature (Lond.). 273: 765-767.

46. Tschopp, T. B., H. J. Weiss, and H. R. Baumgartner. 1974. Decreased adhesion of platelets to subendothelium in von Willebrand's disease. J. Lab. Clin. Med. 83: 296-300.

47. Timmons, S., J. Timmons, S. Graber, and J. Hawiger. 1981. Expression of the Fc receptor on human platelets is regulated by cyclic AMP changes. Thromb. Haemostasis. 46: 172. (Abstr.) 